\title{
VIRTUALIZAÇÃO DA REALIDADE
}

\section{Computadores e telecomunicações permitem desenvolvimento de atividades que dão nova dimensão ao conceito de realidade virtual}

A expressão realidade virtual, embora cunhada recentemente, refere-se a algo que, em certo sentido, sempre foi do conhecimento de todos. Os acontecimentos descritos em obras literárias de ficção ou exibidos na maioria das peças de teatro, filmes e novelas apresentam uma realidade virtual - isto é, uma realidade que, conquanto não exista no plano real, existe no plano do potencial ou imaginado, portanto virtual.

O existir da realidade virtual é um existir em um sentido válido, embora fraco, do termo. Os acontecimentos dessa realidade virtual (livros de fícção, peças, filmes, novelas) sem dúvida afetam nossas vidas, não raro nos emocionam, nos transformam. Algumas pessoas, principalmente as mais simples, confundem essa realidade virtual - que, por paradoxal que pareça, é uma realidade não-real - com a realidade real por redundante que soe essa expressão. Elas detestam determinados atores, porque os personagens que eles representam na tela geralmente são maus, ou se decepcionam quando descobrem que a vida pessoal de um ator não se coaduna com a imagem de integridade identificada com o personagem que encarna na tela.

\section{O AUTOR}

\section{Eduardo O. C. Chaves}

Professor Titular de Filosofia da Educação da Faculdade de Educação da Unicamp.

e-mail:eduardo@chaves.com.br. Coordenador do site Edutecnet www.edutecnet.com.br
Se a expressão realidade virtual se referisse, hoje, somente àquilo que tradicionalmente chamamos de ficção, e que, embora afete nossas vidas, o faz apenas através da imaginação, seria difícil entender por que essa expressão vem aparecendo com tanta freqüência nas revistas, especializadas ou não, e mesmo nos jornais, seja na sua forma original (realidade virtual), seja em formas derivativas (escritório virtual, loja virtual, shopping center virtual, livraria virtual, banco virtual, dinheiro virtual, empresa virtual, conferência virtual, sala de reuniões virtual, biblioteca virtual, cinema virtual, jornal virtual. comunidade virtual, grupo de trabalho virtual, turismo virtual, férias virtuais, sexo virtual etc.).

O sentido da expressão realidade virtual (e de suas formas derivativas) não tem, hoje, entretanto, essa conotação de fictício, apenas imaginado. Quando hoje falamos, por exemplo, em shopping center virtual, não estamos nos referindo a um shopping center que existe apenas na ficção ou na imaginação, e, portanto, apenas em um sentido fraco do termo existir. Estamos nos referindo, isto sim, a um shopping center que existe em um sentido forte do termo, ainda que sua existência ou realidade não possa ser delimitada precisamente em termos espaço-temporais. Tanto o shopping center virtual existe que é possível nele fazer compras, e as compras nele feitas não são de faz-de-conta: são realmente reais, tanto que são entregues na casa de quem as comprou e que, por elas, tem que pagar ainda que com o que poderia ser chamado de dinheiro virtual (como, por exemplo, um cartão de crédito ou de débito). 
A realidade dita virtual na sociedade contemporânea é uma realidade que se distingue, conceitualmente, do reino do ficcional e do imaginário. O que a torna diferente da realidade comumente vista como tal é o fato de que a realidade virtual é uma realidade tornada possível pela revolução da informática - dos computadores e das telecomunicações.

A virtualização da realidade de que trata este artigo pode ser bem ilustrada no caso da chamada comunidade virtual. O termo comunidade tem vários sentidos. Seu sentido principal, porém, talvez seja o que faz referência a um grupo social cujos membros habitam uma determinada região e, em alguns casos, possuem memória e características comuns que individualizam o grupo e lhe dão identidade. Em comunidades pouco coesas, talvez a única característica comum do grupo seja o fato de habitar uma determinada região. Mas em geral as pessoas fazem suas amizades na comunidade em que vivem e essas amizades não raro refletem interesses comuns - comunidade de interesses.

\section{RELAÇÕES SOCIAIS NA COMUNIDADE VIRTUAL}

Uma comunidade virtual, no sentido em que a expressão se emprega hoje, é uma comunidade constituída por pessoas que não habitan necessariamente uma mesma região, mas que se encontraram e se mantiveram unidas através de computadores e telecomunicações - isto é, através das muitas redes de telecomunicações que hoje interligam os usuários de computadores. Os membros de uma comunidade virtual podem habitar até mesmo continentes diferentes e viver em locais distantes, uns dos outros, por vários fusos horários. $\mathrm{O}$ que os une é apenas uma comunidade de interesses, e o interesse comum às vezes é, pelo menos no início, simplesmente encontrar outras pessoas também curiosas em aprender a se comunicar através de seus computadores. Outros interesses comuns aparecem rapidamente e os grupos, às vezes, se quebram em grupos menores para discutir tópicos que só interessam a alguns dos membros do grupo maior. De qualquer forma, é impossível negar que essas comunidades virtuais - porque transcendem o plano espacial e, em certo sentido, também o temporal, visto que a comunicação entre seus membros é assíncrona ${ }^{1}$ - sejam comunidades reais, em que as pessoas genuinamente se interessam umas pelas outras, dão suporte (na forma de informação, conhecimento, apoio emocional e até mesmo auxílio financeiro) umas às outras, por vezes se desentendem e, em alguns casos, até mesmo se apaixonam. (Se o interesse pessoal ou, quem sabe, o amor, leva membros da comunidade virtual a se encontrarem face a face. uma comunidade nãovirtual por vezes se sobrepõe à virtual, criando interações humanas por vezes complicadas.

A comunidade acadêmica e científica que, a despeito de não habitar uma mesma região, já era chamada de comunidade mesmo antes dos computadores e das telecomunicações (já sendo, portanto, em certo sentido, virtual), é hoje eminente e paradigmaticamente virtual, no sentido de que seus membros se comunicam, primária e fundamentalmente, através de seus computadores e das redes criadas para interligar esses computadores, em especial através da Internet, a rede das redes de computadores, instalados em instituições acadêmicas e de pesquisa e desenvolvimento. Não é nenhum exagero dizer que muitos pes-

1. Transmissão assíncrona - é a transmissão de dados, sinais etc. precedida de uma ordem de partida (start) e seguida de uma ordem de parada (stop), portanto não contínua. (N.Ed.) 
quisadores hoje têm mais e melhores relações com pesquisadores com os quais mantêm principalmente encontros virtuais, através da Internet, do que com pesquisadores da mesma instituição, cujas salas ou laboratórios às vezes estão no mesmo prédio ou corredor.

Conferências científicas em regra envolvem, ainda hoje, encontros face a face e, portanto, não podem ser chamadas de virtuais. Mas a organização e o preparo dessas conferências geralmente são feitos por grupos de trabalho virtuais, cujos membros estão a milhares de quilômetros de distância uns dos outros, comunicando-se quase que exclusivamente por correio eletrônico. Os trabalhos científicos a serem apresentados nessas conferências e reuniões são enviados pela rede para o comitê organizador, que os distribui, também pela rede, a avaliadores, que devolvem seus pareceres pelo mesmo meio. É de esperar, porém, que aumente o número de conferências científicas totalmente virtuais, em que os participantes permaneçam em seus próprios locais de trabalho ou em suas próprias casas e se reúnam pela rede, através de textos por eles escritos (teleconferência) ou através da discussão oral de seus textos (teleconferência com áudio) ou até mesmo através de videoteleconferência, que vem sendo paradoxalmente descrita como uma forma de telepresença.

$\mathrm{Na}$ verdade, o chamado correio eletrônico é um correio virtual, pelo qual circulam cor-

Resumo: $\mathrm{O}$ artigo discute o conceito de realidade virtual, demonstrando como, na sociedade contemporânea, ele adquire amplitude, saindo da esfera do imaginário e da possibilidade, para obter materialidade nos intercâmbios da vida social, incluindo-se a transmissão de informaçōes, facilitada pela informática e as telecomunicações. Toma como exemplo a comunidade científica que, cada vez mais, amplia seus contatos e desenvolve atividades através de redes de computadores como a Internet.

Palavras chave: realidade virtual, comunidade virtual, informática, telecomunicações, imaginário respondências eletrônicas. Contudo, seria um erro considerar o correio eletrônico apenas uma recriação digital do correio e das correspondências convencionais. A virtualização do correio acrescentou-lhe dimensões importantes, não existentes antes.

Muitas dessas dimensões representam nítidas vantagens. Primeiramente, a transmissão das mensagens e, portanto, a comunicação é muito mais rápida - virtualmente instantânea. Em segundo, uma mesma mensagem pode ser enviada para vários destinatários simultaneamente. Em terceiro, e mais importante, uma mensagem pode, hoje, em muitos casos, incluir som como, por exemplo, a voz humana e até mesmo imagens (como um vídeo de quem está mandando a mensagem).

Por outro lado, a transmissão de mensagens por cabos convencionais, fibras ópticas ou via satélites coloca sérias questões de segurança, confidencialidade e privacidade que já foram adequadamente equacionadas no correio convencional. Além disso, com a comunicação sem fios, entre computadores, que hoje começa a se viabilizar e até mesmo a se popularizar, a correspondência das pessoas literalmente circulará pelo espectro eletromagnético, com seus textos, sons e imagens digitais, fato que complica ainda mais o problema da segurança, confidencialidade e privacidade da comunicação.

Abstract. The article discusses the virtual reality concept, demonstrating how, in contemporaneous society, it obtains amplitude, leaving the realms of the imaginary and of the possibility, in order to take on materiality in social life's exchanges, including information transmission, facilitated by computer science and telecommunications. It uses as an example the scientific community that increasingly enhances its contacts and carries out activities through computer networks such as the Internet.

Key words: virtual reality, virtual community, computer science, telecommunications, imaginary 